\title{
Tree-ring analysis in natural hazards research - an overview
}

\author{
M. Stoffel and M. Bollschweiler \\ Laboratory of Dendrogeomorphology, Department of Geosciences, University of Fribourg, Chemin du Musée 4, 1700 \\ Fribourg, Switzerland
}

Received: 23 November 2007 - Revised: 22 January 2008 - Accepted: 22 January 2008 - Published: 11 March 2008

\begin{abstract}
The understanding of geomorphic processes and knowledge of past events are important tasks for the assessment of natural hazards. Tree rings have on varied occasions proved to be a reliable tool for the acquisition of data on past events. In this review paper, we provide an overview on the use of tree rings in natural hazards research, starting with a description of the different types of disturbances by geomorphic processes and the resulting growth reactions. Thereafter, a summary is presented on the different methods commonly used for the analysis and interpretation of reactions in affected trees. We illustrate selected results from dendrogeomorphological investigations of geomorphic processes with an emphasis on fluvial (e.g., flooding, debris flows) and mass-movement processes (e.g., landslides, snow avalanche), where lots of data have been generated over the past few decades. We also present results from rockfall and permafrost studies, where data are much scarcer, albeit data from tree-ring studies have proved to be of great value in these fields as well.

Most studies using tree rings have focused on alpine environments in Europe and North America, whereas other parts of the world have been widely neglected by dendrogeomorphologists so far. We therefore challenge researchers to focus on other regions with distinct climates as well, to look on less frequently studied processes as well and to broaden and improve approaches and methods commonly used in tree-ring research so as to allow a better understanding of geomorphic processes, natural hazards and risk.
\end{abstract}

\section{Introduction}

Since the 1970s, tree-ring research has gradually evolved from the pure dating of wood (i.e. dendrochronology, dendroarcheology) to the much broader field of dendroecology, including all areas of science involved in drawing environmental information from tree-ring sequences (Schweingruber, 1996). In this sense, the study of geomorphic pro-

Correspondence to: M. Stoffel

(markus.stoffel@unifr.ch) cesses with tree rings ("dendrogeomorphology") represents one of the many subfields of dendroecology. The approach, first described by Alestalo (1971) and further developed by Shroder (1980), Braam et al. (1987a, b), Butler (1987) and Shroder and Butler (1987), takes advantage of the fact that trees growing in temperate climate zones form yearly increment rings that can be used to precisely date external disturbances.

Since the pioneering studies published in the 1970s and 1980s, a plethora of studies has been performed and various approaches used to date and interpret geomorphic processes posing hazards and risks. This paper therefore aims at providing an overview on (i) tree growth and tree-ring formation; (ii) growth disturbances in trees affected by geomorphic processes; (iii) the most common methods used in dendrogeomorphology (iv) the different geomorphic processes that are commonly analyzed with tree rings, before (v) suggestions are made with respect to future research directions in the field of dendrogeomorphology.

\section{Tree growth and tree-ring formation}

Growth cycles in trees are regulated by the seasonality of climate. In the temperate climate zones, tree-ring formation is limited to the "vegetation period", which roughly lasts from spring to autumn. During the vegetation period, tree-ring formation is driven by a meristem called the vascular cambium. This tissue is located between the secondary xylem (wood) and the secondary phloem (bark) and divides off cells that will be become additional xylem and phloem (Campbell, 1997). Outside the vegetation period, cell formation ceases and the "dormancy" sets in. As a consequence, one distinct increment ring is formed every year, allowing accurate age assessment and chronology development for many different tree species. At the same time, it is worthwhile to note from the beginning that not all species are equally good time keepers.

In conifers (gymnosperms), tree-ring formation can be divided into two distinct periods (Camarero et al., 1998; Rigling et al., 2002; Stoffel et al., 2005a): During the early

Published by Copernicus Publications on behalf of the European Geosciences Union. 

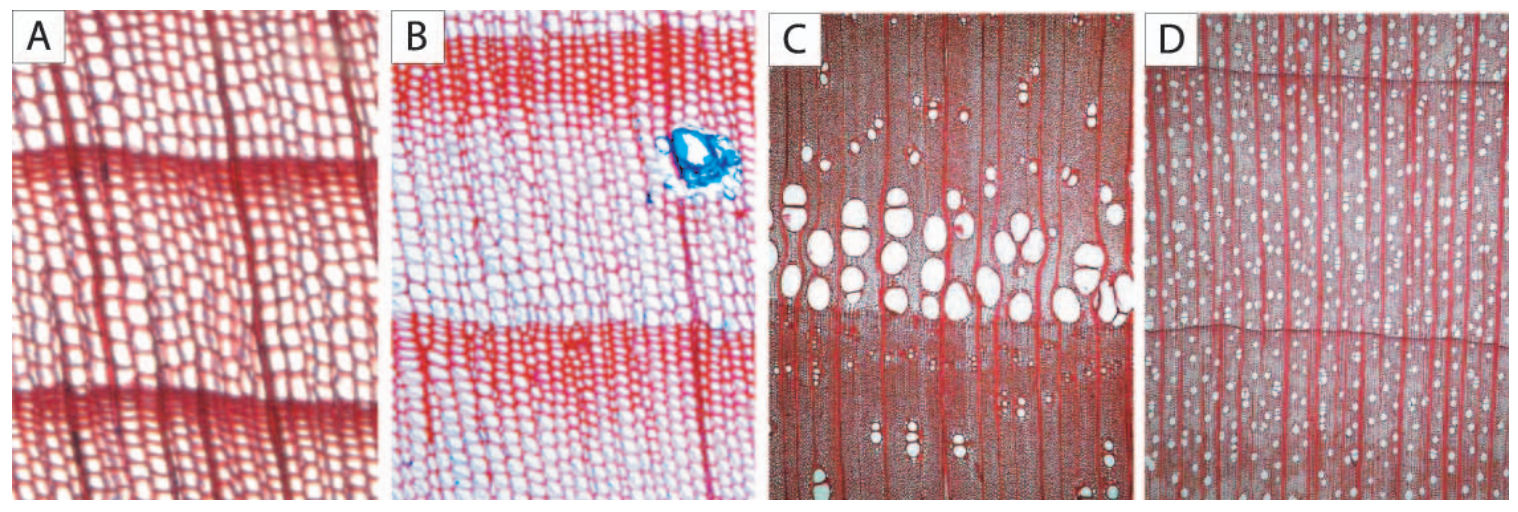

Fig. 1. Micro-sections of tree rings prepared from conifer and broadleaved trees: In (a) Picea abies (L.) Karst. and (b) Pinus cembra L., bands of tracheids form the individual increment rings. In broadleaved trees, tracheids and vessels are formed by the dividing cambium. Depending on the distribution of vessels in the ring, we distinguish between (c) ring-porous (Fraxinus excelsior L.; photo: Schoch et al., 2004) and (d) diffuse-porous angiosperms (Acer pseudoplatanus L.; photo: Schoch et al., 2004).

stages of the vegetation period, reproductive cambium cells form large and thin-walled earlywood cells, so-called tracheids, which primarily serve the transport of nutrients and water. Later in the season, smaller and denser latewood tracheids are produced. Due to their thicker cell walls, these layers are darker in appearance and serve to increase the stability of the tree.

The amount and complexity of tissue formation in broadleaved trees (also called angiosperms or flowering plants) exceeds that of gymnosperms. In addition to the tracheids, the dividing cambium of broadleaved trees also produces vessels. These cells primarily facilitate the flow of water in the stem. Depending on the arrangement of vessels, a distinction is made between wood with statistically scattered pores (diffuse-porous angiosperms) or wood with ringshaped pores (ring-porous angiosperms; Campbell, 1997). Besides the clearly developed types, a number of transitional structures exist. Figure 1 illustrates how tree rings look in conifers (a, b) and in broadleaved trees (c, d).

Growth in trees is driven by internal (biotic and genetic) as well as external (abiotic) factors. The longevity, ageing or sensitivity of a tree represent some of the internal factors driving tree growth, whereas light, temperature, water, nutrient supply, wind, air and soil pollution or geomorphic impacts may influence the radial increment growth of trees as external factors (Schweingruber, 1996).

\section{How do trees react to geomorphic processes?}

Dendrogeomorphological investigations are normally based on the "process-event-response" concept as defined by Shroder (1978). The "process" is represented by any kind of geomorphic agents, such as e.g., a debris flow, rockfall or snow avalanche. In the case of an "event", the geomorphic process will affect a tree, which will react upon the disturbance with a certain growth "response". In the following, the different impacts ("events") that geomorphic processes may have on trees are illustrated and the specific "responses" of trees listed:

\subsection{Wounding of trees (scars) and resin-duct formation}

Scratches on the outer bark and wood-penetrating injuries are a very common feature in trees affected by geomorphic processes (Lundström et al., 2008 ${ }^{1}$ ). Wounds can be observed on the tree's stem (Fig. 2a), in its branches or roots. Provided that the impacting energy was important enough to locally destroy the cambium, increment formation will be disrupted in the injured segment of the tree. In order to minimize the risk of rot and insect attacks after wood-penetrating impacts, the injured tree will (i) compartmentalize the wound (Shigo, 1984) and (ii) almost immediately start with the production of chaotic callus tissue at the edges of the injury (Fig. 2c; Schweingruber, 2001).

Through the production of callus tissue, cambium cells will continuously overgrow the injury from its edges (Fig. 2b; Sachs, 1991; Larson, 1994) and ideally lead to the complete closure of the wound. The wound healing greatly depends on the annual increment rate and the age of the tree, and on the size of the scar.

Following injury, tangential rows of traumatic resin ducts (TRD) are produced in the developing secondary xylem of certain conifer species like e.g., European larch (Larix decidua Mill.), Norway spruce (Picea abies (L.) Karst.) or Silver fir (Abies alba Mill.; Fig. 2d). They extend both tangentially and axially from the injury (Bannan, 1936; Nagy et al., 2000; Bollschweiler et al., 2008b). In contrast, resin ducts are not produced in traumatic and tangential rows in pine trees and cannot therefore be used for the dating of past ge-

\footnotetext{
${ }^{1}$ Lundström, T., Jonsson, M. J., Simon, H., and Stoffel, M.: Assessing reaction and energy absorption of trees exposed to rockfall, J. Exp. Bot, submitted, 2008.
} 

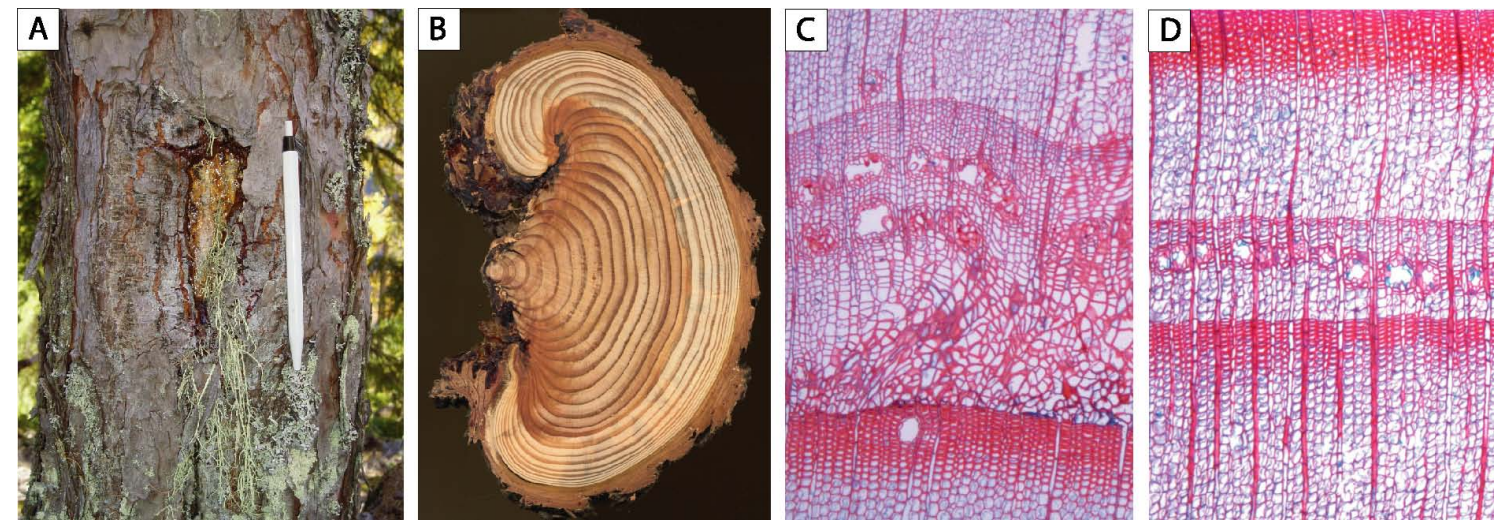

Fig. 2. Injuries in European larch (Larix decidua Mill.): (a) Injured stem (b) Cross-section with overgrowth starting from the lateral edges of the injury. (c) Callus tissue as observed in the overgrowing cell layers bordering the injury. (d) Tangential row of traumatic resin ducts migrating from earlywood towards later portions of the tree ring with increasing distance from the wound (Source: Bollschweiler, 2007).

omorphic events, as this genus produces copious amounts of resin without necessarily suffering from mechanical wounding (Phillips and Croteau, 1999). Given that wounding occurred during the vegetation period of the tree, resin production will start only a few days after the event and axial ducts will emerge within less than three weeks after the disturbing event (Ruel et al., 1998; McKay et al., 2003; Luchi et al., 2005). When analyzing cross-sections, the intra-seasonal position of the first series of TRD can, therefore, be used for the reconstruction of previous events and with monthly precision (Stoffel et al., 2005a, 2008; Stoffel and Beniston, 2006; Stoffel, 2008), provided that the incidence occurred during the vegetation period. With increasing axial and tangential distance from the impact, however, TRD tend to migrate to later portions of the tree ring, which is why the intra-seasonal dating with monthly precision cannot be obtained easily when working with increment cores (Bollschweiler et al., 2008b; Schneuwly and Stoffel, 2008a, b).

Depending on the impact energy and the relative size of the damage, an injured tree will concentrate the formation of tree rings to those parts essential for survival and limit growth in other segments in the years succeeding the impact (Bollschweiler, 2007).

\subsection{Tilting of stems}

The sudden pressure induced by the activity and deposition of material by mass-movement processes (e.g., avalanche snow, debris-flow material) or the slow but ongoing destabilization of a tree through landslide activity or erosion can lead to the inclination of the stem (Lundström et al., 2007, 2008). Tilted trees are quite a common sight in areas affected by geomorphic processes (Fig. 3a) and have therefore been used in many dendrogeomorphological studies to date previous events (e.g., Clague and Souther, 1982; Braam et al., 1987a, b; Fantucci and Sorriso-Valvo, 1999; Casteller et al., 2007).

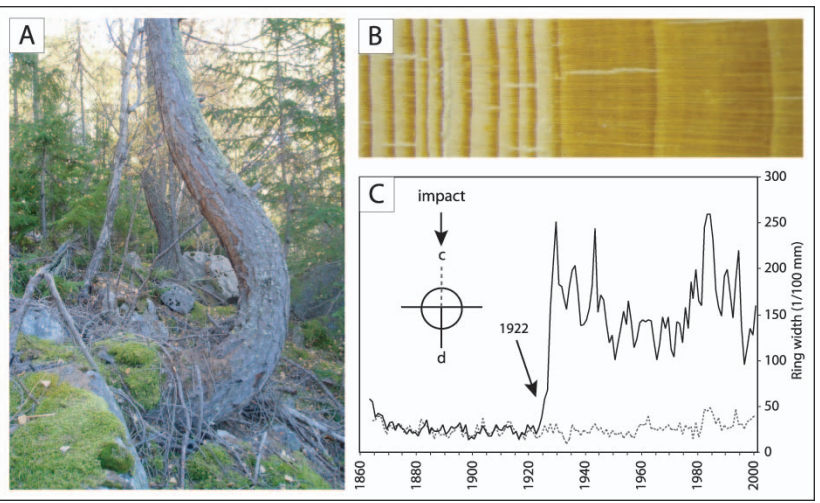

Fig. 3. (a) Tree morphology and (b) cross-sections of a tilted Larix decidua Mill. (D. M. Schneuwly). (c) Increment curves of a Picea abies (L.) Karst. tree tilted by a debris flow in 1922 (Stoffel et al., 2005b).
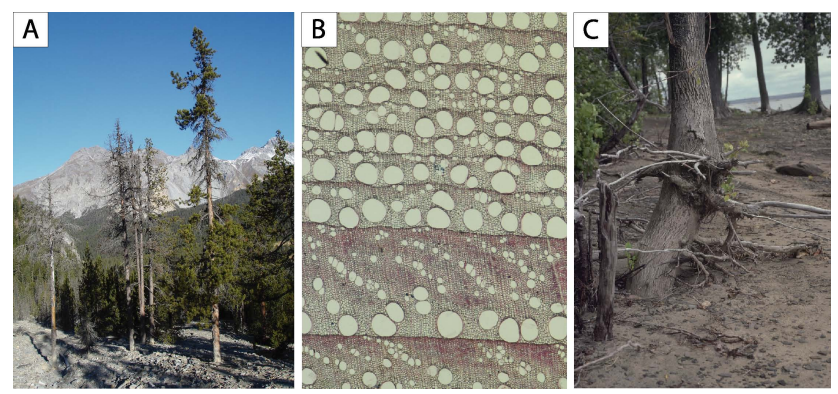

Fig. 4. (a) Sedimentation and subsequent die-off of trees after sedimentation. (b) Micro-section showing an abrupt growth decrease in Castanea sativa Mill. following an event (F. H. Schweingruber). (c) Several levels of adventitious roots in Populus deltoides Bartr. ex Marsh. (F. H. Schweingruber). 

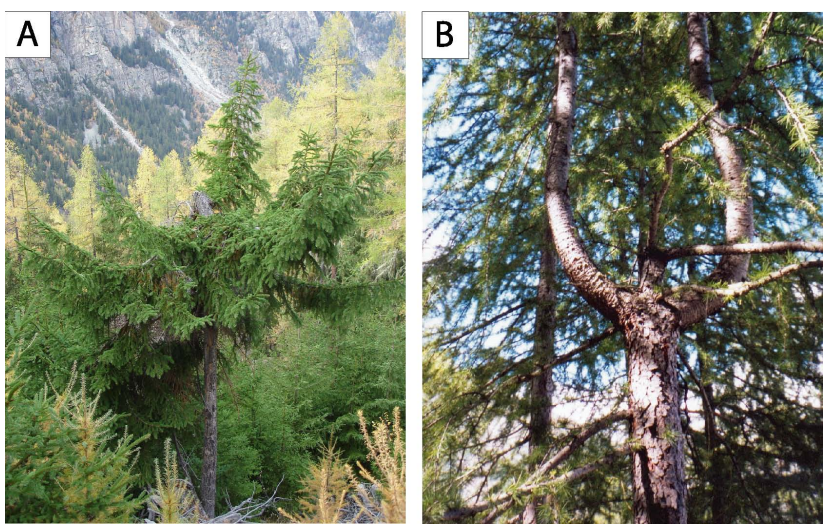

Fig. 5. (a) Picea abies (L.) Karst. decapitated by rockfall. (b) Candelabra growth in Larix decidua Mill. following apex loss.

A tilted tree will always try to regain its vertical position and the reaction will be best visible in that segment of the tree to which the center of gravity has been moved to through the inclination of the stem axis (Mattheck, 1993). In the treering series, eccentric growth will be visible after a tilting event and thus allow accurate dating of the disturbing incidence. In conifer trees, compression wood will be produced on the underside of the trunk. Individual rings will be considerably larger here and slightly darker in appearance as compared to the upslope side (Fig. 3b). The difference in color is due to the much thicker and rounded cell walls of early- and latewood tracheids (Timell, 1986; Schweingruber, 2001). In contrast, broadleaved trees will react upon the tilting of their stem with the formation of tension wood (Westing, 1965; Schweingruber, 1983, 1996, 2001) and the eccentricity will occur on the upper side facing the tilting agent.

In addition to the formation of different types of reaction wood, trees may also respond with reduced growth to their tilting (Bollschweiler, 2007). It is believed that the reduction in annual tree-ring size is related to the destruction of roots resulting from the abrupt or heavy tilting. It is worthwhile to note that the growth decrease will be normally less visible on the side where the reaction wood (i.e. compression or tension wood) is being formed. Figure $3 \mathrm{c}$ provides an example on how the difference in yearly increment looks like in a Picea abies (L.) Karst. tree tilted by a debris flow in 1922.

\subsection{Stem burial}

Debris flows, hyperconcentrated flows, floods or landslides may occasionally bury trees by depositing material around their stem base (Fig. 4a). Growth in these trees will normally be reduced as the supply with water and nutrients will be temporarily disrupted or at least limited (Fig. 4b; LaMarche, 1966; Hupp et al., 1987; Friedman et al., 2005; Malik and
Owczarek, $2008^{2}$ ). Exceptionally, the burial of a stem can also cause a growth increase, provided that the material left by the mass-movement process is rich in nutrients, the water supply guaranteed and the depth of the deposited material is not too important (Strunk, 1995).

As soon as stem burial trespasses a certain threshold, trees will not survive and die from a shortage in water and nutrient supply (Fig. 4a). According to case-study results from the Italian Dolomites (Strunk, 1991), Picea abies (L.) Karst. might tolerate a maximum burial depth of 1.6 to $1.9 \mathrm{~m}$ in these environments dominated by fine-grained debris flows composed of calcareous and dolomitic material (Strunk, 1997). Although there are no data available for other species or lithologies, it is believed that the maximum burial depth tolerated will be (much) less important in regions where debris flows are composed of crystalline rocks and boulders.

Occasionally, buried trees start to produce adventitious roots close to the new ground surface (Fig. 4c; Bannan, 1941). As adventitious roots will be normally formed in the first years succeeding burial (Strunk, 1995), the moment of root sprouting can be used for approximate dating of the sedimentation processes, as shown by e.g., Strunk $(1989,1991)$ or Marin and Filion (1992). In case a tree has been repeatedly buried and several layers of adventitious roots formed, it is even possible to estimate sedimentation depths of individual events at the location of the tree.

\subsection{Decapitation of trees and elimination of branches}

Bouncing rocks and boulders, flowing water with solid charge, debris flows and lahars or the windblast of snow avalanches may cause decapitation of trees (Fig. 5a) or the break-off of branches. The loss of the crown or branches is more common in bigger trees, where stems have lost their suppleness. Apex loss has also been observed in relation with rockfall impacts close to the ground level. In this particular case, the sinusoidal propagation of shockwaves in the stem will result in the break-off of the crown. This phenomenon has been described as the "hula-hoop" effect (Dorren and Berger, 2006; Stoffel, 2005a).

Trees react upon decapitation with distinct growth suppression in the years following the impact (see Fig. 4b). In order to recover, one or several lateral branches will try to take the lead and thus replace the broken crown, resulting in a tree morphology called "candelabra" growth (Fig. 5b; Butler and Malanson, 1985; Stoffel et al., 2005c). In addition, it is not unusual that the shock of the impacting material causes injuries and provokes the formation of TRD as well (see Chapter 3.1).

\footnotetext{
${ }^{2}$ Malik, I. and Owczarek, P.: Dendrochronological records of debris flow activity in a mid-mountain forest zone (Eastern Sudetes - Central Europe), Nat. Hazards Earth Syst. Sci., in revision, 2008.
} 

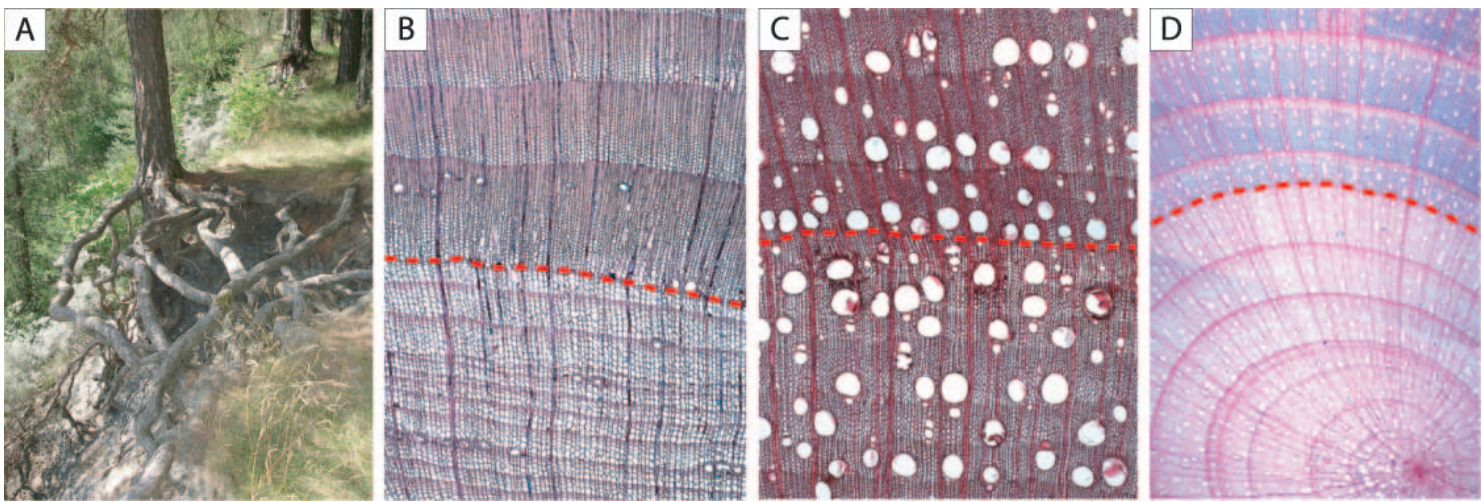

Fig. 6. (a) Exposed roots of Pinus sylvestris L. (b) In Abies alba Mill., larger increment rings with distinct latewood are formed after sudden exposure (dashed red line). (c) Following sudden exposure, the arrangement of vessels in Fraxinus excelsior L. change from diffuse-porous to ring-porous. (d) In addition to cell changes, tension wood is formed in this root of Acer pseudoplatanus L. (Source: Hitz, 2008).
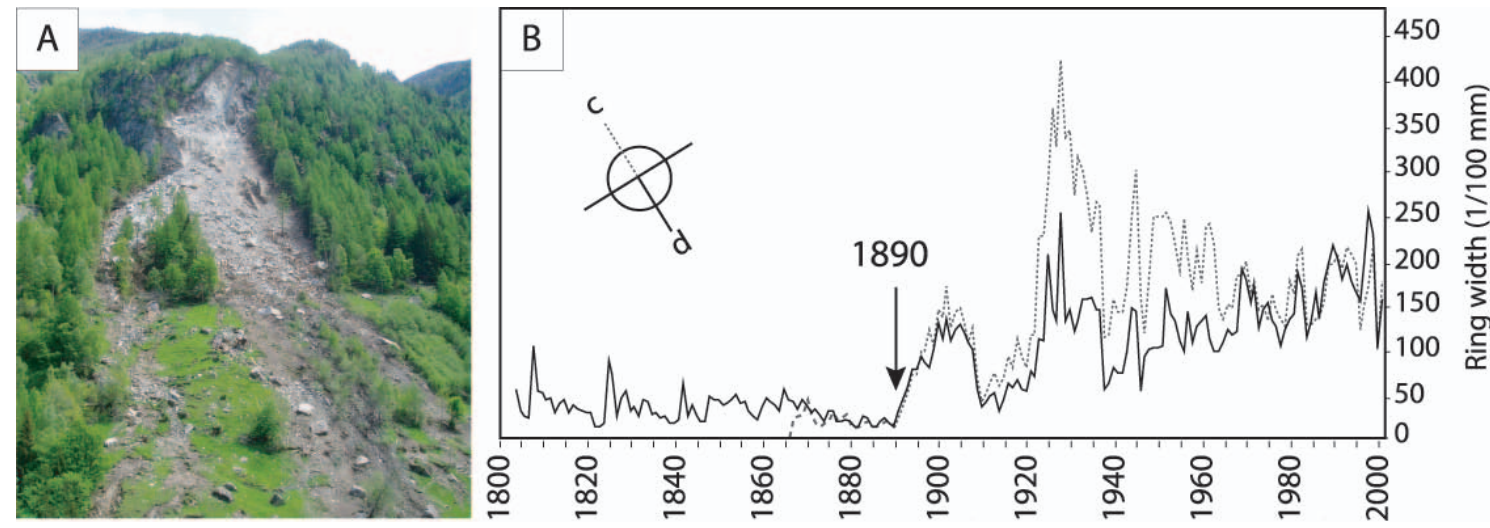

Fig. 7. (a) A rockslide event has eliminated parts of this forest stand while leaving survivor trees uninjured at both sides of the couloir. (b) Increment curves of a survivor tree (Larix decidua) Mill. remaining intact after a major debris flow in 1890 (Stoffel et al., 2005 b).

\subsection{Root exposure}

Erosive processes and the (partial) denudation of roots may generate different growth reactions, both in the stem as in the exposed roots. In addition, the type and intensity of the reaction(s) will strongly depend on the nature of the erosive event, which can occur in the form of a continuous or a sudden process.

Provided that several roots are completely denudated during a sudden erosive event (e.g., debris flow, lahar, flood, landslide), they will no longer be able to fulfill their primary functions and quickly die off. As a consequence, the tree will suffer from a shortage in water and nutrient supply, resulting in suppressed tree growth and the formation of narrow rings in the stem (see Fig. 4b; LaMarche, 1968; Carrara and Carroll, 1979; McAuliffe et al., 2006).

In case that only parts of a root are exposed (Fig. 6a) and its outer end remains in the ground, the root will continue to grow and fulfill its functions. In the exposed part, however, anatomical changes will occur and individual growth rings similar to those in the stem or branches will the formed. The localization of this change in the tree-ring series may allow determination of the moment of exposure (Fig. 6bd; see Gärtner et al., 2001; Bodoque et al., 2006). The continuous exposure of roots is usually related with slow processes and relatively low denudation rates, as observed with the overland flow of rain water, the slow opening of cracks in soils (e.g., soil creep, landslides) and in disintegrated bedrock (e.g., preparation of rockfall, thrusts), along rivers, streams, lakes and oceans (floods, shore erosion) as well as with faulting activity and displacements in relation with earthquake activity. Provided that the roots are gradually exposed with time, it is also possible to determine the erosion rates.

\subsection{Elimination of neighboring trees}

Geomorphic processes do not only disturb trees in their growth, but they can also eliminate trees along channels or couloirs through uprooting and stem breakage while leaving 
their neighbors intact (Fig. 7a). This phenomenon can be observed with e.g., rockfalls, debris flows, lahars, extreme floods, landslides or snow avalanches (Butler, 1979, 1985; Stoffel et al., 2005c).

The uninjured survivor trees will find themselves in a new environment with less competition, more light, nutrients and/or water (Schweingruber, 1996). As a consequence, they will start to produce larger increment rings. However, it has been observed that the growth release in survivor trees can start with a certain delay, which is why this reaction cannot always be used to accurately date past destructive events with yearly precision (Fig. 7b). Nevertheless, the growth release in survivor trees can help to corroborate the dating of events that have been identified in other trees through the study of e.g., scars, tilted stems or abrupt growth decrease (Stoffel et al., 2005b).

\subsection{Colonization of landforms after surface-clearing distur- bances}

Particularly large or devastating mass-movement processes have the potential to eliminate entire forest stands, rendering the reconstruction of previous events impossible with dendrogeomorphological methods. In this case, germination ages of trees growing on the bare surfaces can be used to estimate the time of creation of the new landforms or the time of surface-clearing disturbances to existing landforms. The approach remains, however, a rough estimate, as the time elapsed between the clearing event and the recolonization greatly depends on the nature of the soil, climatic conditions as well as on the availability of seedlings.

This approach of so-called "minimum-age dating" has repeatedly been used to date landforms or to assess the minimum time elapsed since the last devastating event in snow avalanche couloirs, debris-flow channels or floodplains (Sigafoos and Hendricks, 1969; McCarthy and Luckman, 1993; Winter et al., 2002; Pierson, 2007; Bollschweiler et al., 2008a). The assessment of "process inactivity" thus focuses on germination ages via a classical dendrochronological dating of trees. A dendrogeomorphological identification of growth disturbances in the tree-ring series will take place here only to assure that no event has affected the tree since its germination.

\section{Field approach, sampling design and sample prepara- tion}

\subsection{Field approach: geomorphology matters!}

It has been shown in the previous section that different types of growth defects identified in trees can be accurately dated. However, a visual inspection of the increment rings will in no case allow determination of the process that was causing the disturbance. Therefore, a detailed identification of geomorphic processes present at the study site as well as an accurate identification of features related to previous events imperatively need to proceed the sampling of increment cores or cross-sections in the field as well as their analysis and interpretation in the laboratory.

The identification of geomorphic processes and features present on a study site ideally starts with the examination of topographic sheets, geological maps as well as the interpretation of aerial photographs. In addition, technical reports, archival data or newspaper reports can be consulted to obtain data on the time and the locations of occurrence of previous events. In the field, former activity and related geomorphic features need to be identified before a map of all geomorphic deposits and forms can be realized. Depending on the nature of the analysis and the process being studied, the scale of the geomorphic map can vary from 1:100 to 1:10000. Although dendrogeomorphological studies normally focus on one process only (e.g., snow avalanche, debris flow, erosion, landslide, rockfall), features and deposits originating from other processes or anthropogenic activity need to be indicated on the geomorphic map as well, so as to be aware of other influences and to avoid misinterpretation of growth disturbances in trees (see Stoffel et al., 2005b, 2006a). Once finished, the detailed geomorphic map will serve as a basis for the selection and the exact positioning of trees.

In open forest stands, LiDAR data can be used to create a preliminary geomorphic map which can then be verified and/or improved in the field. Alternatively, high-precision GPS or trigonometric devices (theodolite) are of considerable help during the mapping process. On sites with relatively dense forest cover and/or the shielding effect of nearby mountains, the use of high-precision devices is not always possible. Here, mapping needs to be executed with a tape, inclinometer and compass (Lièvre, 2002). In addition to the mapping of erosive and depositional forms, data on the size of blocks deposited or on the nature and density of the vegetation cover (trees, shrubs, herbs, mosses or lichens) can complement the geomorphic mapping and serve as qualitative indicators supporting the tree-ring results.

\subsection{Sampling design: which trees do I select?}

Once the geomorphic map is accomplished, trees are chosen that show clearly visible anomalies in their morphology related to the process under investigation. The choice of trees is (i) based on an outer inspection of its stem surface (i.e. does the tree show obvious signs of past disturbance?) and (ii) on the detailed geomorphic map (i.e. is the tree located in the area influenced by the process studied?).

As soon as a tree is selected for dendrogeomorphological analysis, the following information should be noted: (i) determination of the tree's position within the forms and features; (ii) description and sketches of the visible disturbances in the tree morphology (scars, tilted stem axis, partial burial of the stem, decapitation, destruction of root mass or erosion); (iii) position of the samples taken on the stem surface; 
(iv) diameter measurement at breast height; and (v) data on neighboring trees. A photo documentation of each tree has proven useful for a better understanding and interpretation of reactions in the laboratory. A more detailed description on the documentation and numbering of trees in the field is provided by Stoffel (2005b).

Growth disturbances of past events can be analyzed with cross-sections or increment cores. As forests often have protective functions and as they effectively reduce the risk of rocks, debris, avalanche snow or other elements from reaching transportation corridors and/or inhabited areas (Stoffel et al., 2006a, b; Dorren et al., 2007), trees are sometimes protected and cannot normally be felled for analysis. This is why on forested slopes, tree-ring studies often have to be realized with cores extracted with an increment borer. GrissinoMayer (2003) provides a technical description on how to properly use these increment borers. On the other hand, it is sometimes possible to analyze cross-sections sampled from tree stumps remaining on the slopes after logging activities (Stoffel and Perret, 2006).

The nature of the visible growth defect as observed in the tree's morphology will strongly influence the sampling height, sampling directions and the minimum number of samples to be taken per tree:

In trees with visible scars, previous geomorphic events are most easily dated through the destructive sampling of trees and the preparation of cross-sections taken at the location where the injury is largest. This approach will facilitate an accurate and intra-seasonal identification of the onset of callus tissue production (and TRD formation in certain conifer species) and therefore allows a reconstruction of the impacting event with a very high temporal resolution. Alternatively, wedges can be sawn from the overgrowing callus and an increment core extracted from the side opposite of the wound. In this case, the sampled tree will survive and a reconstruction of the wounding event will be possible as well. In case cross-sections and wedges can not be taken from the injured trees, at least two increment cores need to be extracted from the overgrowing callus and the side opposite to the wound. Special attention needs to be addressed to the sampling of cores from the overgrowing callus: Samples taken inside the overgrowing tissue will provide an incomplete tree-ring record, as wounds are closed from their edges. On the other hand, samples taken too far away from the callus growth will not show any signs of the disturbing event at all and thus prevent dating. Figure 8 illustrates the right position for the extraction of increment cores in injured trees. In addition and in the case of certain conifer species, TRD formation will be delayed with increasing distance from the wound and thus influence the intra-seasonal dating quality (Bollschweiler et al., 2008b; Schneuwly and Stoffel, 2008b).

Tilted stems are best analyzed with at least two increment cores extracted per tree, one in the direction of the tilting and the other on the opposite side of the trunk. The reaction wood will be visible on the tilted side in conifer trees (= compres-

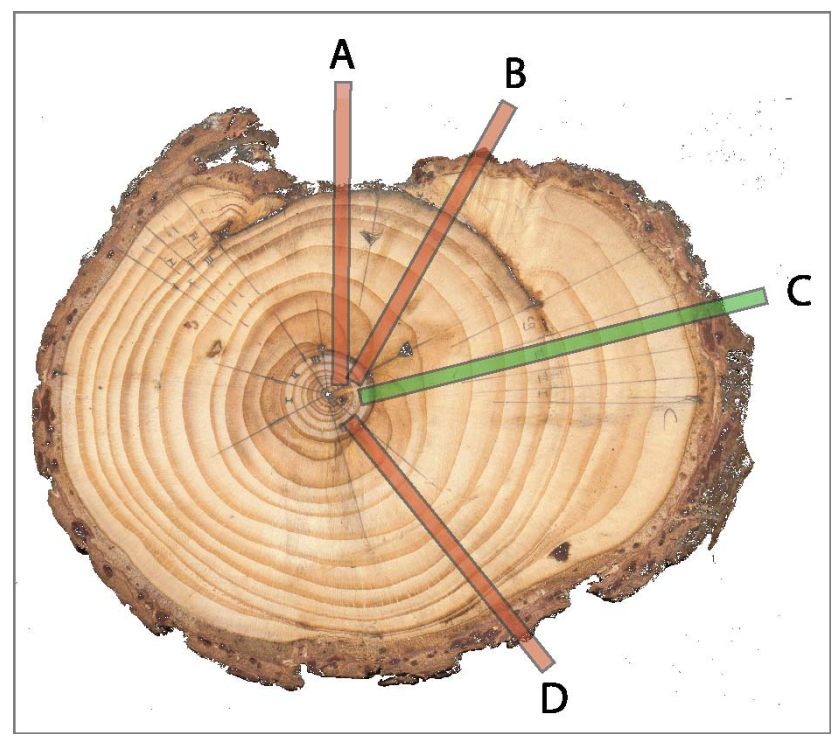

Fig. 8. When sampling injured trees, special attention needs to be addressed to the sampling position. Samples taken (a) inside the wound or (b) from the overgrowing callus tissue will provide an incomplete tree-ring record, as wounds are closed from their edges. (c) Ideally, increment cores are extracted just next to the injury where the presence of overgrowing callus tissue and TRD will allow accurate dating. (d) Cores taken too far away from the wound will not necessarily show signs of the disturbing event and thus prevent dating.

sion wood) and on the side opposite to the tilting direction in the broadleaved trees (= tension wood). Individual cores are best extracted at the location where the tilting is strongest based on an outer inspection of the tree morphology.

In the case of buried stem bases, the sampling of two increment cores in opposite directions (ideally from the upslope and the downslope side) will normally allow accurate reconstruction of the event that has led to the sedimentation of material around the stem's base. It is best to sample these trees as close to ground level as possible (ca. $20-40 \mathrm{~cm}$ ) to extract a maximum number of tree rings and obtain a maximum of information. In a similar way, decapitated and survivor trees are normally sampled at comparable heights, but in any case below the level of decapitation.

The analysis of exposed roots is normally based on crosssections, as they regularly show partially missing or absent rings. The position of samples needs to be carefully noted with respect to the ground surface or the non-eroded parts of the root. They will be essential for the understanding and interpretation of continuous erosion processes and the determination of denudation rates (LaMarche, 1968; Bodoque et al., 2006).

The germination of trees on new landforms is best determined by counting the annual growth rings in increment cores taken from the root crown level. However, branches, obstacles and rot may sometimes require sampling positions higher up on the stem. In these cases, an age correction factor 
needs to be added to compensate for the time a tree takes to grow to sampling height (McCarthy et al., 1991). A heightage correction can be achieved by dividing the tree height by the number of tree rings to get an average rate for the yearly apical increment. Thereafter, the sampling height is divided by this yearly increment so as to obtain the number of missing rings (Bollschweiler et al., 2008a). In addition, the number of missing rings has to be estimated whenever the pith is not present on the core. This correction can be undertaken using a transparent sheet with concentric rings (Bosch and Gutiérrez, 1999; Gutsell and Johnson, 2002). An age correction also needs to be applied for the assessment of the colonization time gap, i.e. the time elapsed between the last event and the germination of pioneer trees (Pierson, 2007).

In addition to the disturbed trees sampled on the site, undisturbed reference trees need to be selected from a nearby forest stand. As a rule, the selection of trees for the reference chronology shall be based on the following two criteria: (i) absence of obvious signs of injuries or diseases to minimize non-climatic influences on ring growth; (ii) oldest trees in order to maximize the age of sampled trees and the length of the tree-ring chronology. In contrast to the disturbed trees, two increment cores are extracted perpendicular to the slope and at breast height $(\approx 130 \mathrm{~cm})$. In general, about 30 reference trees per species need to be sampled so as to minimize the potential influence of geomorphic processes and hidden growth disturbances.

\subsection{Laboratory approach: sample preparation and analysis}

In the laboratory, samples are normally analyzed and data processed following the standard procedures described in Stokes and Smiley (1968) or Bräker (2002). Single steps of sample analysis generally include surface preparation, counting of tree rings, skeleton plots (Schweingruber et al., 1990) as well as ring-width measurements using a digital positioning table connected to a stereo microscope and a time-series analysis program.

In a first step, a reference chronology is built with the increment cores of the undisturbed reference trees. Ring widths of the increment cores are measured, before each ring-width measurement series is indexed and standardized in order to remove age trends or effects of stand dynamics (Cook and Kairiukstis, 1990; Vaganov et al., 2006). As typical with tree-ring chronologies, sample depth (i.e. the number of measured ring-width series included in the chronology) usually decreases with time before the sampling year (Wigley et al., 1984). In order to guarantee adequacy of sample replication in the early years of the chronology, reference chronologies should be limited to the time period with a sample depth of at least five trees.

Ring-widths of the disturbed samples are measured as well and the series are then graphically and statistically compared with the reference chronology. The graphical comparison may include overlay plotting of mean growth curves derived from the disturbed samples with the reference chronology, whereas statistical procedures normally comprise the analysis of parallelisms ('Gleichläufigkeit' or $W$ statistics; Eckstein and Bauch, 1969; Schweingruber, 1983) and crossdate indices (e.g., Rinn, 1989) These statistical comparisons can be realized using dendrochronological software such as e.g., Arstan (Cook and Holmes, 1984), T.S.A.P. (Rinntech, 2007) or WinDendro (Guay et al., 1992; Régents Instruments, 2007). In addition, the crossdating accuracy between ring-width series of individual disturbed trees and the reference chronology can be evaluated with the Cofecha software (Holmes, 1983; Grissino-Mayer, 2001). Overall, the graphical and statistical comparison of disturbed with reference trees serves the separation of insect attacks or climatically driven fluctuations in tree growth from growth disturbances caused by geomorphic processes. Further details on the realization of reference chronologies, the statistical approaches used in dendrochronology or on the improvement of growth series with missing rings can be found in Fritts (1976), Cook (1987), Cook and Kairiukstis (1990) or Vaganov et al. (2006).

Once all tree-ring series checked and missing rings added, growth curves are analyzed visually to identify the tree's reactions to geomorphic processes like the initiation of abrupt growth reduction or recovery (Schweingruber, 2001; McAuliffe et al., 2006). In the case of tilted stems, the growth curve data are analyzed to approximate the moment of the tilting (Braam et al., 1987; Fantucci and Sorriso-Valvo, 1999; Fig. 3c), but in addition, the appearance of the cells (i.e. structure of the reaction wood cells) is investigated on the samples as well. Other features like callus tissue overgrowing scars or the presence of tangential rows of traumatic resin ducts (TRD) formed following cambium damage can only be identified through a visual inspection of the cores and cross-sections (e.g., Stoffel et al., 2005c, 2007; Perret et al., 2006; Bollschweiler et al., 2008b). Finally, the first decade of juvenile growth should never be included in the analysis, as tree rings in seedlings tend to be more susceptible to snow pressure or the fraying and browsing of ungulates and produce more reaction wood or resin ducts per unit area in general.

Provided that highly-resolved data exist on the timing and different periods of radial growth, the position of callus tissue (and TRD) within a tree ring can be used to assess the intraseasonal timing of process activity in a particular year with monthly precision (see Stoffel and Beniston, 2006; Stoffel, 2008). Alternatively and as to corroborate the results on the intra-seasonal dating, data can also be compared with existing precipitation records from local meteorological stations or with archival data on known events (Stoffel et al., 2005b, 2008).

All growth reactions identified in the samples are noted in order to identify events. Except for processes with limited volumes involved (e.g., single rocks or boulders involved in 
rockfall events; Stoffel et al., 2005c, 2006b; Moya et al., 2008), one growth disturbance identified in one single tree will not be considered an event. This is why it seems important to note that event histories reconstructed with tree rings will never be complete and always represent "minimum frequencies". The identification of events can be based on quantitative or semi-quantitative approaches:

Butler et al. (1987) suggest a "tree-ring response index" being dictated by the nature and geographical extent of the specific hazard under study. The authors argue that more samples and the use of a higher minimum response index would allow greater confidence in the event chronology constructed from tree rings, but they do not provide a definitive minimum sample size for dendrogeomorphological analyses. It is suggested that chronologies for geographically discrete processes (e.g., snow avalanche) should aim for a high sample density, whereas studies focusing on processes such as slow landslides or the movement of permafrost bodies would require less dense, but larger sample size.

Stoffel et al. (2006a, 2007) or Bollschweiler et al. (2007, 2008a), in contrast, stress the importance of site selection, as the identification of geomorphic features and the position of trees in the geomorphic context represents the most important aspect of tree-ring analyses. Instead of basing the identification of events on a minimum number of trees, the spatial distribution of trees simultaneously showing a growth disturbance after debris-flow, snow avalanche and flooding events is being analyzed, as small or erosive events will not necessarily leave existing channels or couloirs and only cause growth disturbances in a (very) limited number of trees at specific (breakout) locations in the field.

\section{What natural hazards processes are analyzed with tree rings?}

Dendrogeomorphological analyses have been widely used over the last few decades in the analysis and reconstruction of a whole plethora of geomorphic processes. This chapter does not, therefore, claim to be complete, but will only refer to results from selected pioneering publications and introduce what are considered to be significant follow-up papers for the different natural hazards processes. It also seems worthwhile to note that many pioneering tree-ring studies have been realized in the American Southwest and from the early 1960s on, which is years before "dendrogeomorphology" was officially introduced by the Finnish geographer Jouko Alestalo in 1971.

Interestingly, dendrochronological research of geomorphic processes did not start with the analysis of stem samples, but with root analyses. In the early 1960s, LaMarche (1961; 1968) was, for the first time, assessing erosion rates of exposed roots in the White Mountains, California. Further root studies were realized in the Southwest in the 1970s (e.g., Carrara and Carroll, 1979) and until today, with the most recent study published by McAuliffe et al. (2006) and Scuderi et al. (2008) ${ }^{3}$, documenting four centuries of erosion and sedimentation history in Arizona. More recently, erosion research also started to evolve on the Iberian Peninsula, where sheet erosion was analyzed with Pinus sylvestris L. (Bodoque et al., 2006; Rubiales et al., 2008). While in all the before-mentioned studies, conifers were used for the assessment of erosion in roots, Hitz et al. (2008) have only recently demonstrated the potential of Fraxinus excelsior L. roots for the identification of sudden or continuous erosion processes. Finally, LaMarche (1966) was again the first to work on shore erosion processes, thus reconstructing 800 years of geomorphic activity. More recent studies were realized on the shores of the Upper St. Lawrence estuary in Québec (Bégin et al., 1991) and on the shores of Lago Bolsena in Central Italy (Fantucci, 2007).

The first studies of natural hazards processes based on growth rings extracted from stems and branches focused on flooding events. The theoretical background for the study of flooding and sedimentation processes was provided by Sigafoos (1964). Helley and LaMarche (1968) applied the techniques so as to determine the recurrence interval of flood events in Northern California. Later studies in the United States focused on floods in the White River (Arkansas; Bedinger, 1971) or high summer flows and floods in the Potomac River (Yanosky, 1982, 1983, 1984). St. George and Nielson $(2000,2003)$ have analyzed anatomical changes ("flood rings") in Quercus macrocarpa to identify 19thcentury high-magnitude floods in the Red River (Canada). In Europe, only a few studies have focused on floods so far, for instance the one published by Astrade and Bégin (1997) documenting recent spring floods in the Saône river (France) in rings of Populus tremula L. and Quercus robur L. Tardiff and Bergeron (1997) studied the occurrence of ice floods through a dendrochronological analysis of ice-scarred Thuja occidentalis L. growing on the shore of Lake Duparquet (Canada).

In contrast to the study of erosion or flood processes, $d e$ bris flows have abundantly been analyzed in the European Alps over the last few years and decades. After the pioneering studies of Hupp (1984) or Hupp et al. (1987) conducted on the slopes of Mount Shasta (California), dendrogeomorphology has been extensively used by Strunk (1989, 1991, 1997) to reconstruct debris-flow activity in the Italian Dolomites. In contrast to the first investigations, he also focused on the germination of adventitious roots in buried stems so as to reconstruct burial depths and the history of debris flows since the Little Ice Age. More recently, several torrents have been investigated in the Swiss Alps (Baumann and Kaiser, 1999; Stoffel et al., 2005b; Bollschweiler and Stoffel, 2007; Bollschweiler et al., 2007, 2008a). Analyses

\footnotetext{
${ }^{3}$ Scuderi, L., McFadden, L., and McAuliffe, J.: Dendrogeomorphically derived slope and stream response to decadal and centennial scale climate variability: Implications for downstream sedimentation, Nat. Hazards Earth Syst. Sci., in revision, 2008.
} 
culminated in the extensive study of 1100 conifers growing on the cone of the Ritigraben torrent yielding data on 123 debris-flow incidences since AD 1570, with most of them dated with monthly precision (Stoffel and Beniston, 2006; Stoffel et al., 2008).

The tree-ring based analysis of landslides started in the 1980s with several case studies realized in the Québec region (Bégin and Filion, 1985, 1988; Filion et al., 1991) and in Barcelonnette, French Alps (Braam et al., 1987a, b). More recently, Corominas and Moya (1999) have analyzed recent landslides in the basin of the Llobregat River (Pyrenees) and identified two different rainfall patterns triggering landslides. In Italy, dendrogeomorphology has been repeatedly used for the identification of landslide dynamics in Calabria or the Apennines (Fantucci and McCord; 1995; Fantucci and Sorriso-Valvo 1999; Stefanini, 2004) and results have been compared with meteorological data.

The occurrence of past snow avalanches has quite frequently been analyzed with tree rings over the last three decades, with Schaerer's (1972) publication on the vegetation in avalanche terrain at Rogers Pass in British Columbia (Canada) forming one of the pioneering studies. For a long time, tree-ring based analysis of snow avalanche activity was almost exclusively used in the States and especially in the Glacier National Park, where Butler (1979, 1985) and Butler and Sawyer (2008) published a series of papers on the tree-ring based dating of snow avalanches. More recently and in the light of risk assessment, attention turned towards the identification of more "extreme events" and the dating of high-magnitude snow avalanches on e.g., the Gaspé Peninsula (Boucher et al., 2003; Dubé et al., 2004) and in the Glacier National Park (Butler and Sawyer, 2008). Amazingly, only a very limited number of studies have been published about snow avalanches in the European Alps: Stoffel et al. (2006a) studied a cone affected by snow avalanches descending from three different couloirs and were able to distinguish the damage induced by the windblast from that induced by snow and transported material. A few years ago, tree-ring based analysis of snow avalanches has been initiated in the Pyrenees (Muntán et al., 2004, 2008 ) and in Patagonia (Mundo et al., 2007; Casteller et al., 2008 ${ }^{5}$ ). Larocque et al. (2001) used impacts scars, TRD and reaction wood to analyze frequency-magnitude relationships of slushflows (i.e. liquefied snow) on the Gaspé Peninsula.

Surprisingly, and despite the potential of dendrogeomorphological methods, rockfall activity has only rarely been

\footnotetext{
${ }^{4}$ Muntán, E., Oller, P., García, C., Martí, G., García, A. and Gutiérrez, E.: Reconstructing snow avalanches in the Southeastern Pyrenees. Nat. Hazards Earth Syst. Sci., in review, 2008.

${ }^{5}$ Casteller, A., Christen, M., Villalba, R., Martínez, H., Stöckli, V., Leiva, J., and Bartelt, P.: Validating numerical simulations of snow avalanches using dendrochronology: The Cerro Ventana event in Northern Patagonia, Argentina, Nat. Hazards Earth Syst. Sci., in revision, 2008.
}

studied through the analysis of tree-ring sequences (Stoffel, 2006). First studies of rock-tree interactions focused on the identification and dating of large rock avalanches (e.g., Moore and Mathews, 1978; Butler et al., 1986) rather than on the reconstruction of the much more frequent release of individual rocks and boulders during rockfall events. Lafortune et al. (1997) were probably the first to focus on rockfall events, but with the aim of reconstructing sedimentation rates and forest edge dynamics. The first investigations analyzing the seasonality, frequency and spatial patterns of rockfall activity were only very recently realized by Stoffel et al. (2005a, c), yielding data on 400 years of rockfall activity on a forested slope in the Swiss Alps. The methods have since been applied to other sites in Switzerland by Perret et al. (2006) or Schneuwly and Stoffel (2008a, b), providing a reliable basis for the analysis of rockfall risks and the quality assessment of rockfall models (Stoffel et al., 2006b).

In a similar way, comparably little research has been performed on geomorphic processes occurring in glacier and periglacial environments. Research in these highaltitude/high-latitude regions started with Zoltai's (1975) study of soil movements on permafrost. Only little work has been realized on that topic ever since, with Jakob's (1995) analysis of movement rates of gelifluction lobes forming the only other publication on this comparably slow process. Similarly, only limited dendrogeomorphological data exist on the rise and evolution of thermokarst. Agafonov et al. (2004), for instance, report that the development of thermokarst over the last 50 years depended primarily on increasing precipitation rather than increasing air temperature. Movements in rockglacier bodies have, in contrast been documented in several case-studies. In his pioneering investigation of a glacier-like boulder deposit on the Table Cliffs Plateau (Utah), Shroder (1978) documented 200 years of movements and suggested that precipitation would possibly have been the trigger for the main episodes of movements. Other studies on movements in permafrost complexes have been realized elsewhere in North America ever since (Giardino et al., 1984; Carter et al., 1999; Cannone and Gerdol, 2003; Bachrach et al., 2004), but are completely missing in the European Alps or other alpine regions.

Geological hazards are another field where dendrogeomorphology can provide valuable data on the timing and the locations of past events. As a result, tree rings have extensively been used to study century-old earthquakes along the San Andreas Fault in California or in the Seattle region (Jacoby et al., 1988, 1992; Jacoby, 1997). More recently, Bekker (2004) has analyzed spatial differences in the response of trees to normal faulting in relation with the Hebgen Lake earthquake. Since the catastrophic explosion of Mount St. Helens in 1980, tree rings have also been used for the analysis and reconstruction of non-documented volcanic eruptions of the past. Yamaguchi $(1983,1985)$, for instance, demonstrated that there have been recent prehistoric explosive eruptions of Mount St. Helens prior to the big 
1980 blast. Based on the analysis of frost rings and other dendrochronological evidence, D’Arrigo et al. (2001) dated millennia-old volcanic eruptions with Mongolian and Northern Siberian trees, whereas Salzer and Hughes (2007) managed to identify 5000 years of volcanic eruptions through the study of Bristlecone pine trees. Solomina et al. $(2008)^{6}$ have dated several events of the Sheveluch volcano (Kamchatka, Russia) through the tree-ring dating of logs that have been killed during an eruption in the 17 th century and conserved in the deposits of the pyroclastic flow.

\section{Outlook and future research directions}

Over the last few decades, dendrochronology has continuously evolved from a supplementary tool for the dating of wood to a widely recognized science and a real backbone for Holocene chronology reconstructions (Solomina, 2002). Dendrogeomorphology has been widely used in the analysis of snow avalanche, debris-flow, landslide or flood analysis. In contrast, tree-ring based reconstructions of past rockfall activity have been comparatively scarce so far, yet yielded promising results. Based on the physics of the processes involved and the nature of damage observed in the trees' morphology, we have to believe that there is a potential for the tree-ring based analysis of other hazards as well, such as glacier-lake outburst floods (GLOF), ice avalanches or the occurrence of volcanic lahars. In a similar way, it appears worthwhile to focus on certain non-geomorphic hazards in the future as well, such as the incidence of tornados, hurricanes and winter storms or even the occurrence of past tsunamis.

In addition to the pure dating and reconstruction of past geomorphic incidences at the site level, results from different regions should be compared and efforts made towards a more complete understanding of the influence of climatic triggers or endogenic causes on the occurrence of events (Solomina, 2002). A comparison of regional or supra-regional event chronologies with (dendro-)climatological networks (e.g., Briffa et al., 1992, 2001) would certainly help in this respect. For the moment, comparative dendrogeomorphological studies focusing on the regional behavior and triggers of geomorphic events as well as the contemporary and potential future risks they may pose remain very scarce (Stoffel and Bollschweiler, 2007).

Further, tree-ring based research on geomorphic processes has largely focused on mountain regions in general and the North American chains and European Alps in particular. Although there seems to be quite some potential for dendrogeomorphological studies, tree rings have only exceptionally been used in other regions of the world to assess past geomor-

\footnotetext{
${ }^{6}$ Solomina, O., Pavlova, I., Curtis, A., Jacoby, G., Ponomareva, V., and Pevsner, M.: Constraining recent Shiveluch volcano eruptions (Kamchatka, Russia) by means of dendrochronology, Nat. Hazards Earth Syst. Sci., in revision, 2008.
}

phic process activity, such as e.g., the analysis of landslides in subtropical Argentina (Paolini et al., 2005) and Greece (Papadopoulos et al., 2007) or the reconstruction of snow avalanches in Patagonia (Mundo et al., 2007; Casteller et al., $2008^{5}$ ). We therefore call for more dendrogeomorphological research on landslides, snow avalanches and other geomorphic processes in other regions of the world, including e.g., South America (Andes, Patagonia), the Indian subcontinent (Himalayas), Africa (e.g., Atlas Mountains) and in Eastern Europe or Russia (Balkan, Altay and Siberian Mountains, Caucasus, Ural).

Besides the application of commonly accepted dendrogeomorphological techniques and the dating of events, future research activities should also focus on physiological and chemical reactions of trees to disturbance as well as to species that have been widely disregarded so far (e.g., broadleaved trees, shrubs or perennial herbs). Does the intensity of an impact or the duration of an events influence the nature of the reaction? After how much time will a tree show first signs to an event and are there different response times for different types of reactions? More research is primarily needed on the chemical initiation and actual formation of reaction wood and tangential rows of resin ducts. New insights could be generated through the artificial infliction of wood-penetrating wounds, the burial of stems, exposure of roots or the destabilization (tilting) of trees. Alternatively, it would also be feasible to analyze trees that have been damaged during well known events in the past (Bollschweiler et al., 2008b). Essential progress should be expected through detailed wood anatomical investigations and the analysis of cell changes following disturbance.

The past is the key to the future and a detailed knowledge of previous process activity will greatly help the understanding and management of contemporary and maybe even the forecasting of potential future incidences. It is therefore important to realize that besides the pure dating of events and the creation of valuable event chronologies, dendrogeomorphological data should also be used as a tool and as the most complete database for the assessment of hazards and risks (Stoffel and Bollschweiler, 2007), the identification of infrastructure or settlement being exposed to danger (Perret et al., 2006, Bollschweiler et al., 2007) or for the accuracy assessment and subsequent improvement of process-based geomorphic models (Stoffel et al., 2006b).

Essential progress has been made in most of the above fields over the last few years, but more work is needed to further promote this unique technique. Research performed with new species or parts of trees will need to go beyond simple ring counting and include more rigorous statistical comparisons of ring chronologies or event-response replications, otherwise, investigations can lead to spurious errors. At the end, tree-ring research will help to even better understand the complex dynamics, mechanisms or triggering factors of geomorphic processes and to mitigate or reduce the problems they may pose. 
Acknowledgements. The authors are grateful to D. R. Butler, J. F. Shroder and O. Solomina for their insightful comments on the manuscript. O. M. Hitz, D. M. Schneuwly, W. Schoch and F. H. Schweingruber are warmly acknowledged for photo credits.

Edited by: F. Guzetti

Reviewed by: D. Butler and two other anonymous referees

\section{References}

Agafonov, L., Strunk, H., and Nuber, T.: Thermokarst dynamics in Western Siberia: insights from dendrochronological research, Palaeogeogr. Palaeoclimatol. Palaeoecol., 209, 183-196, 2004.

Alestalo, J.: Dendrochronological interpretation of geomorphic processes, Fennia, 105, 1-139, 1971.

Astrade L. and Bégin Y.: Tree-ring response of Populus tremula L. and Quercus robur $\mathrm{L}$. to recent spring floods of the Saône river, France. Ecoscience, 4, 232-239, 1997.

Bachrach, T., Jakobsen, K., Kinney, J., Nishimura, P., Reyes, A., Laroque, C. P., and Smith, D. J.: Dendrogeomorphological assessment of movement at Hilda rock glacier, Banff National Park, Canadian Rocky Mountains, Geogr. Ann., 86A, 1-9, 2004.

Bannan, M. W.: Variability in root structure in roots of native Ontario conifers, Bull. Torrey Bot. Club, 68, 173-194, 1941.

Bannan, M. W.: Vertical resin ducts in the secondary wood of the Abietineae, New Phytol., 35, 11-46, 1936.

Baumann, F. and Kaiser, K. F.: The Multetta debris fan, eastern Swiss Alps: a 500-year debris flow chronology, Arct. Antarc. Alp. Res., 31(2), 128-134, 1999.

Bedinger, M. S.: Forest species as indicators of flooding in the lower White River valley, Arkansas, U.S., Geol. Surv. Prof. Pap., 750C, C248-C253, 1971.

Bégin, Y. and Filion, L.: Age of landslides along Grande Rivière de la Baleine estuary, eastern coast of Hudson Bay, Quebec (Canada), Boreas, 17, 289-299, 1988.

Bégin, Y. and Filion, L.: Analyse dendrochronologique d'un glissement de terrain dans la region du Lac de l'Eau Claire (Québec nordique), Can. J. Earth Sci., 22, 175-182, 1985.

Bégin, Y., Langlais, D., and Cournoyer, L.: Tree-ring dating of shore erosion events (Upper St. Lawrence estuary, eastern Canada), Geogr. Ann. 73A, 53-59, 1991.

Bekker, M. F.: Spatial variation in the response of tree rings to normal faulting during the Hebgen Lake Earthquake, Southwestern Montana, USA, Dendrochronologia, 22, 53-59, 2004.

Bodoque, J. M., Díez-Herrero, A., Martín-Duquea, J. F., Rubiales, J. M., Godfrey, A., Pedraza, J., Carrasco, R. M., and Sanz, M. A.: Sheet erosion rates determined by using dendrogeomorphological analysis of exposed tree roots: Two examples from Central Spain., Catena, 64, 81-102, 2006.

Bollschweiler, M.: Spatial and temporal occurrence of past debris flows in the Valais Alps - results from tree-ring analys is, GeoFocus, 20, 182 pp., 2007.

Bollschweiler, M. and Stoffel, M.: Debris flows on forested cones reconstruction and comparison of frequencies in two catchments in Val Ferret, Switzerland, Nat. Hazards Earth Syst. Sci., 7, $207-$ 218, 2007,

http://www.nat-hazards-earth-syst-sci.net/7/207/2007/.

Bollschweiler, M., Stoffel, M., Ehmisch, M., and Monbaron, M.: Reconstructing spatio-temporal patterns of debris-flow activity with dendrogeomorphological methods, Geomorphology, 87(4), 337-351, 2007.

Bollschweiler, M., Stoffel, M., and Schneuwly, D. M.: Dynamics in debris-flow activity on a forested cone - a case study using different dendroecological approaches, Catena, 72, 67-78, 2008a.

Bollschweiler, M., Stoffel, M., Schneuwly, D. M., and Bourqui, K.: Traumatic resin ducts in Larix decidua stems impacted by debris flows, Tree Physiol., 28, 255-263, 2008b.

Bosch, O. and Gutiérrez, E.: La sucésion en los bosques de Pinus uncinata del Pirineo. De los anillos de crecimiento a la historia del bosque, Ecología 13, 133-171, 1999.

Boucher, D., Filion, L., and Hétu, B.: Reconstitution dendrochronologique et fréquence des grosses avalanches de neige dans un couloir subalpin du mont Hog's Back, en Gaspésie centrale (Québec), Géogr. Phys. Quat. 57, 159-168, 2003.

Braam, R. R., Weiss, E. E. J., and Burrough, A.: Spatial and temporal analysis of mass movement using dendrochronology, Catena, 14, 573-584, 1987a.

Braam, R. R., Weiss, E. E. J., and Burrough, A.: Dendrogeomorphological analysis of mass movement: A technical note on the research method, Catena 14, 585-589, 1987b.

Bräker, O. U.: Measuring and data processing in tree-ring research - a methodological introduction, Dendrochronologia, 20(1-2), 203-216, 2002.

Briffa, K. R., Jones, P. D., and Schweingruber, F. H.: Tree-Ring Density Reconstructions of Summer Temperature Patterns across Western North America since 1600, J. Clim. 735-754, 1992.

Briffa, K. R., Osborn, T. J., Schweingruber, F. H., Harris, I. C., Jones, P. D., Shiyatov, S. G., and Vaganov, E. A.: Low-frequency temperature variations from a northern tree ring density network, J. Geophys. Res., 106, 2929-2942, 2001.

Butler, D. R.: Teaching general principles and applications of dendrogeomorphology, J. Geol. Educ., 35, 64-70, 1987.

Butler, D. R.: Vegetational and geomorphic change on snow avalanche path, Glacier National Park, Great Basin Nat., 45, 313-317, 1985.

Butler, D. R.: Snow avalanche path terrain and vegetation, Glacier National Park, Montana. Arct. Alp. Res., 11, 17-32, 1979.

Butler, D. R. and Sawyer, C.: Review and comparison of the different methods used for dating high-magnitude snow avalanches, Nat. Hazards Earth Syst. Sci., 8, this special issue, 2008.

Butler, D. R. and Malanson, G. P.: A history of high-magnitude snow avalanches, southern Glacier National Park, Montana, USA, Mountain Res. Dev. 5, 175-182, 1985.

Butler, D. R., Malanson, G. M., and Oelfke, J. G.: Tree-ring analysis and natural hazard chronologies: minimum sample sizes and index values, Prof. Geogr., 39, 41-47, 1987.

Butler, D. R., Oelfke, J. G., and Oelfke, L. A.: Historic rockfall avalanches, northeastern Glacier National Park, Montana, U.S.A. Mountain Res. Dev., 6: 261-271, 1986.

Camarero, J. J., Guerrero-Campo, J., and Gutiérrez, E.: Tree-ring growth and structure of Pinus uncinata and Pinus sylvestris in the Central Spanish Pyrenees, Arct. Alp. Res. 30(1), 1-10, 1998.

Campbell, N. A.: Biologie. Spektrum, Heidelberg, Berlin, Oxford, 1482 pp., 1997.

Cannone, N. and Gerdol, R.: Vegetation as an ecological indicator of surface instability in rock glaciers, Arct. Antarc. Alp. Res., 35, 384-390, 2003. 
Carrara, P. E. and Carroll, T. R.: The determination of erosion rates from exposed tree roots in the Piceance Basin, Colorado, Earth Surf. Process., 4, 307-317, 1979.

Carter, R., LeRoy, S., Nelson, T., Laroque, C. P., and Smith, D. J.: Dendroglaciological investigations at Hilda Creek rock glacier, Banff National Park, Canadian Rocky Mountains, Geogr. Phys. Quat., 53, 365-371, 1999.

Casteller, A., Stöckli, V., Villalba, R., and Mayer, A. C.: An evaluation of dendroecological indicators of snow avalanches in the Swiss Alps. Arct. Antarc. Alp. Res., 39, 218-228, 2007.

Clague, J. J. and Souther, J. G.: The Dusty Creek landslide on Mount Caylay, British Columbia, Can. J. Earth Sci. 19, 524-539, 1982.

Cook, E. R.: The decomposition of tree-ring series for environmental studies, Tree-Ring Bull., 47, 37-59, 1987.

Cook, E. R. and Holmes, R. L.: Program ARSTAN and users manual. Lamont Doherty Geological Observatory, Palisades, 28 pp., New York, 1984.

Cook, E. R. and Kairiukstis, L. A.: Methods of dendrochronology - Applications in the environmental sciences, Kluwer, London, 329 pp., 1990.

Corominas, J. and Moya, J.: Reconstructing recent landslide activity in relation to rainfall in the Llobregat River basin, Eastern Pyrenees, Spain, Geomorphology, 30, 79-93, 1999.

D’Arrigo, R., Frank, D., Jacoby, G., and Pederson, N.: Spatial response to major volcanic events in or about AD 536, 934 and 1258: Frost rings and other dendrochronological evidence from Mongolia and Northern Siberia, Clim. Change, 49, 239-246, 2001.

Dorren, L. K. A., Berger, F., Jonsson, M., Krautblatter, M., Moelk, M., Stoffel, M., and Wehrli, A.: State of the art in rockfall-forest interaction, Schweiz. Z. Forstwes., 158(6), 128-141, 2007.

Dorren, L. K. A. and Berger, F.: Energy dissipation and stem breakage of trees at dynamic impacts, Tree Physiology 26, 63-71, 2006.

Dubé, S., Filion, L., and Hétu, B.: Tree-ring reconstruction of highmagnitude snow avalanches in the Northern Gaspé Peninsula, Québec, Canada, Arct. Antarc. Alp. Res., 36, 555-564, 2004.

Eckstein, D. and Bauch, J.: Beitrag zur Rationalisierung eines dendrochronologischen Verfahrens und zur Analyse seiner Aussagesicherheit, Forstwiss. Cent. bl, 88, 230-250, 1969.

Fantucci, R.: Dendrogeomorphological analysis of shore erosion along Bolsena lake (Central Italy), Dendrochronologia, 24, 6978, 2007.

Fantucci, R. and Sorriso-Valvo, M.: Dendrogeomorphological analysis of a slope near Lago, Calabria (Italy), Geomorphology, 30, 165-174, 1999.

Fantucci, R. and McCord, A.: Reconstruction of landslide dynamic with dendrochronological methods, Dendrochronologia 13, 4358, 1995.

Filion, L., Quinty, F., and Bégin, Y.: A chronology of landslide activity in the valley of Rivière du Gouffre, Charlevoix, Quebec. Can. J. Earth Sci. 28, 250-256, 1991.

Friedman, J. M., Vincent, K. R., and Shafroth, P. B.: Dating floodplain sediments using tree-ring response to burial, Earth Surf. Process. Landf. 30, 1077-1091, 2005.

Fritts, H. C.: Tree rings and climate, Academic Press, London, 567 pp., 1976.
Gärtner, H., Schweingruber, F. H., and Dikau, R.: Determination of erosion rates by analyzing structural changes in the growth pattern of exposed roots, Dendrochronologia, 19, 81-91, 2001.

Giardino, J. R., Shroder, J. F., and Lawson, M. P.: Tree ring analysis of movement in a rock-glacier complex on Mount Mestas, Colorado, USA, Arct. Alp. Res., 16, 299-309, 1984.

Grissino-Mayer, H. D.: A manual and tutorial for the proper use of an increment borer, Tree-Ring Res., 59, 63-79, 2003.

Grissino-Mayer, H. D.: Evaluating crossdating accuracy: a manual and tutorial for the computer program COFECHA, Tree-Ring Res., 57, 205-221, 2001.

Guay, R., Gagnon, R., and Morin, H.: A new automatic and interactive tree-ring measurement system based on a line scan camera, For. Chron., 68, 138-141, 1992.

Gutsell, S. L. and Johnson, E. A.: Accurately ageing trees and examining their height-growth rates: implications for interpreting forest dynamics, J. Ecol., 90, 153-166, 2002.

Helley, E. J. and LaMarche, V. C.: December 1964, a 400-year flood in Northern California. U.S., Geological Survey Professional Paper 600-D, D34-D37, 1968.

Hitz, O. M.: Dendrogeomorphologische Prozessanalyse zum Schwemmholzaufkommen und Rekonstruktion von Ufererosion zweier voralpiner Wildbachsysteme. PhD thesis, University of Fribourg, in press, 2008.

Hitz, O. M., Gärtner, H., Heinrich, I., and Monbaron, M.: First time application of Ash (Fraxinus excelsior L.) roots to determine erosion rates in mountain torrents, Catena, 72, 248-258, 2008.

Holmes, R. L.: Computer assisted quality control in tree-ring dating and measurement, Tree-Ring Bull., 43, 69-78, 1983.

Hupp, C. R.: Dendrogeomorphic evidence of debris flow frequency and magnitude at Mount Shasta, California, Env. Geol. Wat. Sci. 6, 121-128, 1984.

Hupp, C. R., Osterkamp, W. R., and Thornton, J. L.: Dendrogeomorphic evidence and dating of recent debris flows on Mount Shasta, northern California. U.S., Geol. Surv. Prof. Pap., 1396B, 1-39, 1987.

Jacoby, G. C.: Application of tree ring analysis to paleoseismology, Rev. Geophys., 35, 109-124, 1997.

Jacoby, G. C., Williams, P. L., and Buckley, B. M.: Tree ring correlation between prehistoric landslides and abrupt tectonic events in Seattle, Washington, Science 258, 1621-1623, 1992.

Jacoby, G. C., Sheppard, P. R. and Sieh, K. E.: Irregular recurrence of large earthquakes along the San Andreas Fault. Evidence from trees, Science, 241, 196-199, 1988.

Jakob, M.: Dendrochronology to measure average movement rates of gelifluction lobes, Dendrochronologia, 13, 141-146, 1995.

Lafortune, M., Filion, L., and Hétu, B.: Dynamique d'un front forestier sur un talus d'éboulis actif en climat tempéré froid (Gaspésie, Québec), Géogr. Phys. Quat., 51, 1-15, 1997.

Larocque, S. J., Hétu, B., and Filion, L.: Geomorphic and dendroecological impacts of slushflows in central Gaspé Peninsula (Québec, Canada) Geogr. Ann., 83, 191-201, 2001.

LaMarche, V. C.: Rates of slope degradation as determined from botanical evidence, White Mountains, California. U.S. Geol. Surv. Prof. Pap., 352-I, 1968.

LaMarche, V. C.: An 800-year history of stream erosion as indicated by botanical evidence, U.S. Geol. Surv. Prof. Pap. 550D, 83-86, 1966. 
LaMarche, V. C.: Rate of slope erosion in the White Mountains, California, Geol. Soc. Am. Bull., 72, 1579-1580, 1961.

Larson, P. R.: The vascular cambium. Development and structure, Springer, Berlin, 725 pp., 1994.

Lièvre, I.: Détermination de la fréquence de laves torrentielles sur le torrent du Ritigraben (Valais, Suisse), Diploma thesis, University of Fribourg, Fribourg, 2002.

Luchi, N., Ma, R., Capretti, P., and Bonello, P.: Systemic induction of traumatic resin ducts and resin flow in Austrian pine by wounding and inoculation with Sphaeropsis sapinea and Diplodia scrobiculata, Planta, 221, 75-84, 2005.

Lundström, T., Stoffel, M., and Stöckli, V.: Fresh-stem bending of fir and spruce, Tree Physiol., 28, 355-366, 2008.

Lundström, T., Heiz, U., Stoffel, M., and Stöckli, V.: Fresh-wood bending: linking the mechanic and growth properties of a Norway spruce stem. Tree Physiol., 27, 1229-1241, 2007.

Marin, P. and Filion, L.: Recent dynamics of subarctic dunes as determined by tree-ring analysis of white spruce, Hudson Bay, Québec, Quat. Res. 38, 316-330, 1992.

Mattheck, C.: Design in der Natur. Rombach Wissenschaft, Reihe Ökologie 1, 242 pp., 1993.

McAuliffe, J. R., Scuderi, L. A. and McFadden, L. D.: Tree-ring record of hillslope erosion and valley floor dynamics: Landscape responses to climate variation during the last $400 \mathrm{yr}$ in the Colorado Plateau, northeastern Arizona. Glob. Planet. Change, 50, 184-201, 2006.

McCarthy, D. P. and Luckman, B. H.: Estimating ecesis for treering dating of moraines: a comparative study from the Canadian Cordillera, Arct. Alp. Res., 25, 63-68, 1993.

McCarthy, D. P., Luckman, B. H. and Kelly, P. E.: Sampling heightage error correction for spruce seedlings in glacial forefields, Canadian Cordillera, Arct. Alp. Res., 23, 451-455, 1991.

McKay, S. A. B., Hunter, W. L., Godard, K. A., Wang, S. X., Martin, D. M., Bohlmann, J., and Plant, A. L.: Insect attack and wounding induce traumatic resin duct development and gene expression of (-)-Pinene synthase in Sitka spruce, Plant Physiol., 133, 368-378, 2003.

Moore, D. P. and Mathews, W. H.: The Rubble Creek landslide, southwestern British Columbia, Can. J. Earth Sci. 15, 10391052, 1978.

Moya, J., Corominas, J. and Perez Arcas, J.: Dendrogeomorphological determination of the frequency of rockfalls at Solà d'Andorra (Andorra Principality): sampling strategies and completeness of the record, Geophys. Res. Abstr., 10, 09965, 2008.

Mundo, I A., Barrera, M. D. and Roig, F. A.: Testing the utility of Nothofagus pumilio for dating a snow avalanche in Tierra del Fuego, Argentina. Dendrochronologia 25, 19-28, 2007.

Muntán, E., Andreu, L., Oller, P., Gutiérrez, E. and Martínez, P. : Dendrochronological study of the Canal del Roc Roig avalanche path: first results of the Aludex project in the Pyrenees, Ann. Glaciol. 38, 173-179, 2004.

Nagy, N. E., Franceschi, V. R., Solheim, H., Krekling, T. and Christiansen, E., 2000. Wound-induced traumatic resin duct formation in stems of Norway spruce (Pinaceae): anatomy and cytochemical traits. Am. J. Bot. 87, 302-313, 2000.

Papadopoulos, A. M., Mertzanis, A., and Pantera, A.: Dendrogeomorphological observations in a landslide on Tymfristos mountain in Central Greece. In: Stokes, A., Spanos, I., Norris, J. E. and Cammeraat, E. (eds.) Eco- and ground bio-engineering: The use of vegetation to improve slope stability. Springer, Berlin, Heidelberg, New York, 223-230, 2007.

Paolini, L., Villalba, R., and Grau, H. R.: Precipitation variability and landslide occurrence in a subtropical mountain ecosystem of NW Argentina, Dendrochronologia, 22, 175-180, 2005.

Perret, S., Stoffel, M. and Kienholz, H.: Spatial and temporal rockfall activity in a forest stand in the Swiss Prealps - a dendrogeomorphological case study, Geomorphology, 74(1-4), 219-231, 2006.

Phillips, M. A., Croteau, R.: Resin-based defenses in conifers, Trends Plant Sci., 4, 184-190, 1999.

Pierson, T. C.: Dating young geomorphic surfaces using age of colonizing Douglas fir in southwestern Washington and northwestern Oregon, USA, Earth Surf. Process. Landf., 32, 811-831, 2007

Régents Instruments. WinDendro - for tree-ring, stem, wood density analysis and measurement, http://www.regentinstruments. com/, 2007.

Rigling, A., Bräker, O., Schneiter, G., and Schweingruber, F. H.: Intra-annual tree-ring parameters indicating differences in drought stress of Pinus sylvestris forests within the Erico-Pinion in the Valais (Switzerland), Plant Ecol., 163, 105-121, 2002.

Rinn, F.: Time Series Analysis and Presentation V3.0., Reference Manual. Rinntech, Heidelberg, 264 pp., 1989.

Rinntech: LINTAB-Precision ring by ring. http://www.rinntech. com/Products/Lintab.htm, 2007.

Rubiales, J. M., Bodoque, J. M., Ballesteros, J. A. and DíezHerrero, A.: Response of Pinus sylvestris roots to sheet-erosion exposure: An anatomical approach, Nat. Hazards Earth Syst. Sci., 8, this special issue, 2008.

Ruel, J. J., Ayres, M. P. and Lorio, P. L.: Loblolly pine responds to mechanical wounding with increased resin flow, Can. J. For. Res., 28, 596-602, 1998.

Sachs, T.: Pattern formation in plant tissue, Cambridge University Press, 246 pp., Cambridge, 1991.

Salzer, M. W. and Hughes, M. K.: Bristlecone pine tree rings and volcanic eruptions over the last $5000 \mathrm{yr}$, Quat. Res., 67, 57-68, 2007.

Schaerer, P. A.: Terrain and vegetation of snow avalanche sites at Rogers Pass, British Columbia, B. C. Geogr. Series, 14, 215-222, 1972.

Schneuwly, D. M. and Stoffel, M.: Spatial analysis of rockfall activity, bounce heights and geomorphic changes over the last 50 years - A case study using dendrogeomorphology, Geomorphology, in press, 2008a.

Schneuwly, D. M. and Stoffel, M.: Tree-ring based reconstruction of the seasonal timing, major events and origin of rockfall on a case-study slope in the Swiss Alps, Nat. Hazards Earth Syst. Sci., 8, 203-211, 2008b, http://www.nat-hazards-earth-syst-sci.net/8/203/2008/.

Schoch, W., Heller, I., Schweingruber, F. H., and Kienast, F.: Wood anatomy of central European Species, http://www.woodanatomy. ch, 2004.

Schweingruber, F. H., Eckstein, D., Serre-Bachet, F., and Bräker, O. U.: Identification, presentation and interpretation of event years and pointer years in dendrochronology, Dendrochronologia, 8 , 9-39, 1990.

Schweingruber, F. H.: Dendroökologische Holzanatomie. Paul Haupt, Bern, Stuttgart, Wien, 472 pp., 2001. 
Schweingruber, F. H.: Tree rings and environment, Dendroecology, Paul Haupt, Bern, Stuttgart, Wien, 609 pp., 1996.

Schweingruber, F. H.: Der Jahrring: Standort, Methodik, Zeit und Klima in der Dendrochronologie. Paul Haupt, Bern, Stuttgart, Wien, 243 pp., 1983.

Shigo, A. L.: Compartmentalization: a conceptual framwork for understanding how trees grow and defend themselves, Annu. Rev. Phytopathol. 22, 189-214, 1984.

Shroder, J. F.: Dendrogeomorphology: review and new techniques of tree-ring dating, Prog. Phys. Geogr. 4, 161-188, 1980.

Shroder, J. F.: Dendrogeomorphological analysis of mass movement on Table Cliffs Plateau, Utah, Quat. Res., 9, 168-185, 1978.

Shroder, J. F. and Butler, D. R.: Tree-ring analysis in the earth sciences. In: Jacoby, G. C. and Hornbeck, J. W (eds.), Proc. Int. Symp. "Ecological Aspects of Tree-Ring Analysis", Lamont Doherty Geological Observatory, 186-212, 1987.

Sigafoos, R. H.: Botanical evidence of floods and floodplain deposition, U.S. Geol. Surv. Prof. Pap., 485-A, 1964.

Sigafoos, R. S. and Hendricks, E. L.: The time interval between stabilization of alpine glacial deposits and establishment of tree seedlings, U.S. Geol. Surv. Prof. Pap., 650-B, B89-B93, 1969.

Solomina, O.: Dendrogeomorphology: research requirements, Dendrochronologia, 20, 233-245, 2002.

Stefanini, M. C.: Spatio-temporal analysis of a complex landslide in the Northern Apennines (Italy) by means of dendrochronology, Geomorphology, 63, 191-202, 2004.

St. George, S. and Nielsen, E.: Palaeoflood records for the Red River, Manitoba, Canada, derived from anatomical tree-ring signatures, Holocene, 13, 547-555, 2003.

St. George, S. and Nielsen, E.: Signatures of high-magnitude 19thcentury floods in Quercus macrocarpa tree rings along the Red River, Manitoba, Canada, Geology, 28, 899-902, 2000.

Stoffel, M.: Dating past geomorphic processes with tangential rows of traumatic resin ducts, Dendrochronologia, in press, 2008.

Stoffel, M.: A review of studies dealing with tree rings and rockfall activity: The role of dendrogeomorphology in natural hazard research, Nat. Hazards, 39, 1, 51-70, 2006.

Stoffel, M.: Assessing the vertical distribution and visibility of scars in trees, Schweiz. Z. Forstwes., 156(6), 195-199, 2005a.

Stoffel, M.: Spatio-temporal analysis of rockfall activity into forests - results from tree-ring and tree analyses, $\mathrm{PhD}$ thesis, Faculty of Science, University of Fribourg, GeoFocus, 12, 1-188, 2005b.

Stoffel, M. and Bollschweiler, M.: Tree-ring based reconstruction of past debris-flow events and assessment of future risks in 32 torrents of the Valais Alps (Switzerland), Quat. Int., 167/8, 398399, 2007.

Stoffel, M. and Beniston, M.: On the incidence of debris flows from the early Little Ice Age to a future greenhouse climate: a case study from the Swiss Alps, Geophys. Res. Lett, 33, L16404, 2006.

Stoffel, M. and Perret, S.: Reconstructing past rockfall activity with tree rings: some methodological considerations, Dendrochronologia, 24(1), 1-15, 2006.

Stoffel, M., Conus, D., Grichting, M. A., Lièvre, I., and Maître, G.: Unraveling the patterns of late Holocene debris-flow activity on a cone in the central Swiss Alps: chronology, environment and implications for the future, Glob. Planet. Change, 60, 222-234, 2008.

Stoffel, M., Bollschweiler, M., and Hassler, G. R.: Differentiating events on a cone influenced by debris-flow and snow avalanche activity - a dendrogeomorphological approach, Earth Surf. Process. Landf., 31(11), 1424-1437, 2006a.

Stoffel, M., Wehrli, A., Kühne, R., Dorren, L. K. A., Perret, S., and Kienholz, H.: Assessing the protective effect of mountain forests using a 3-D model, Forest Ecol. Manage., 225, 113-122, $2006 \mathrm{~b}$.

Stoffel, M., Lièvre, I., Monbaron, M., and Perret, S.: Seasonal timing of rockfall activity on a forested slope at Täschgufer (Valais, Swiss Alps) - a dendrochronological approach, Z. Geomorphol, 49(1), 89-106, 2005a.

Stoffel, M., Lièvre, I., Conus, D., Grichting, M., Raetzo, H., Gärtner, H. W., and Monbaron, M.: 400 years of debris flow activity and triggering weather conditions: Ritigraben, Valais, Switzerland, Arct. Antarc. Alp. Res., 37(3), 387-395, 2005b.

Stoffel, M., Schneuwly, D., Bollschweiler, M., Lièvre, I., Delaloye, R., Myint, M., and Monbaron, M.: Analyzing rockfall activity (1600-2002) in a protection forest - a case study using dendrogeomorphology, Geomorphology, 68, (3-4), 224-241, 2005c.

Stokes, M. A. and Smiley, T. L.: An introduction to tree-ring dating, University of Chicago Press, Chicago, 73 pp., 1968.

Strunk, H.: Dating of geomorphological processes using dendrogeomorphological methods, Catena, 31, 137-151, 1997.

Strunk, H.: Dendrogeomorphologische Methoden zur Ermittlung der Murfrequenz und Beispiele ihrer Anwendung, Roderer, Regensburg, 196 pp., 1995.

Strunk, H.: Frequency distribution of debris flow in the Alps since the "Little Ice Age". Zeitschrift für Geomorphologie N. F., Supplement 83, 71-81, 1991.

Strunk, H.: Dendrogeomorphology of debris flows, Dendrochronologia, 7, 15-25, 1989.

Tardiff, J. and Bergeron, Y.: Ice-flood history reconstructed with tree-rings from the southern boreal forest limit, western Québec, Holocene, 7, 291-300, 1997.

Timell, T. E.: Compression wood in Gymnosperms, Springer, Berlin, 2150 pp., 1986.

Vaganov, E. A., Hughes, M. K., and Shashkin, A. V.: Growth dynamics of conifer tree rings. Images of past and future environments, Springer, Berlin, Heidelberg, New York, 350 pp., 2006.

Westing, A. H.: Formation and function of compression wood in gymnosperms II, Bot. Rev., 34, 51-78, 1965.

Wigley, T. M. L., Briffa, K. R., and Jones, P. D.: On the average value of correlated time series, with applications in dendroclimatology and hydrometeorology, J. Clim. Appl. Meteorol., 23, 201-203, 1984.

Winter, L. E., Brubaker, L. B., Franklin, J. F., Miller, E. A., and DeWitt, D. Q.: Initiation of an old-growth Douglas fir stand in the Pacific Northwest: a reconstruction from tree-ring records, Can. J. For. Res., 32, 1039-1056, 2002.

Yamaguchi, D. K.: Tree-ring evidence for a two-year interval between recent prehistoric explosive eruptions of Mount St. Helens, Geology, 13, 554-557, 1985.

Yamaguchi, D. K.: New tree ring dates for recent eruptions of Mount St. Helens, Quat. Res., 20, 246-250, 1983.

Yanosky, T. M.: Documentation of high summer flows on the Potomac River from the wood anatomy of ash trees, Water Resour. Bull., 20, 241-250, 1984.

Yanosky, T. M.: Evidence of floods on the Potomac River from anatomical abnormalities in the wood of flood-plain trees, U.S. Geol. Surv. Prof. Pap., 1296, 1983. 
Yanosky, T. M.: Effects of flooding upon woody vegetation along parts of the Potomac River flood plain, U.S. Geol. Surv. Prof. Pap., 1206, 1982.
Zoltai, S. C.: Tree ring record of soil movements on permafrost, Arctic Alpine Res., 7, 331-340, 1975. 